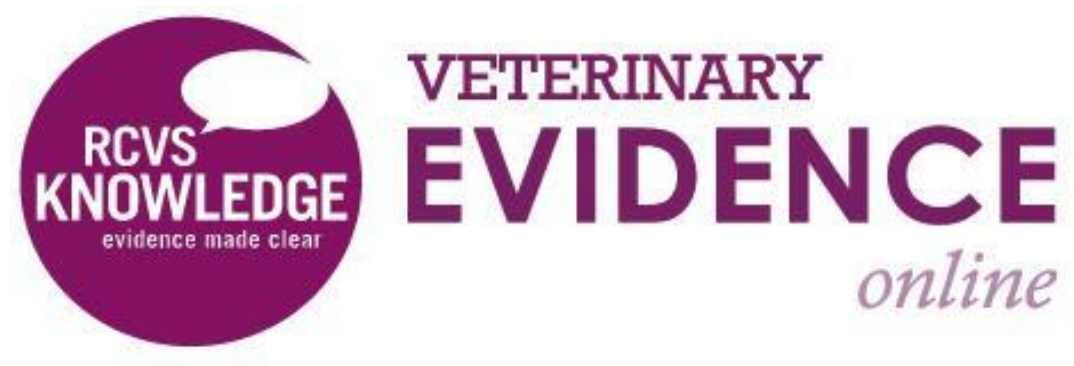

\title{
A Survey of the Non-clinical Benefits of EBVM
}

Sarah Hauser BSc (Hons) MPA MPP ${ }^{1 *}$

Elizabeth L. Jackson BAg (Hons) MBA PhD SFHEA ${ }^{1}$

\footnotetext{
${ }^{1}$ Royal Veterinary College, Hawkshead Lane, North Mymms, Hatfield, Hertfordshire, AL9 7TA, United Kingdom

*Corresponding Author (shauser@rvc.ac.uk)
}

ISSN: 2396-9776

Published: 03 Aug 2017

in: Vol 2, Issue 3

DOI: http://dx.doi.org/10.18849/ve.v2i3.102

Reviewed by: Nieky van Veggel (MSc, CBiol, FHEA) and Dr Sebastian Arlt

\section{OPEN
ACCESS \\ PEER \\ REVIEWED}


Objective: This study aims to add non-clinical benefits to the virtues for adopting Evidence-based Veterinary Medicine (EBVM). The objective is to quantify the commercial benefits of EBVM through an online survey of veterinary professionals, giving clear indications of the key areas of non-clinical benefits of EBVM. Further, the study aims to outline barriers to the wider implementation of EBVM and find preferred ways of overcoming those barriers.

Background: A PICO-based literature review (Hauser and Jackson, 2016) found that while there are some papers suggesting a link between the practice of EBVM and better non-clinical benefits such as client satisfaction, a single study, focusing on the non-clinical benefits of EBVM, had yet to be conducted. This study builds on the findings of an exploratory study (Jackson and Hauser, 2017) outlining key areas of non-clinical benefits of EBVM: increased client satisfaction and retention, improved reputation, confidence, as well as employee engagement.

Evidentiary value: This online survey of veterinary professionals ( $n=407)$ provides evidence for practitioners, universities and other veterinary staff regarding the non-clinical benefits of EBVM, the barriers to a wider adoption of the practice and ways of overcoming those barriers.

Methods: The online survey of veterinary professionals was conducted during September - October 2016 and contained 23 questions. Survey participation was voluntary and the data used for analysis were de-identified.

Results: The survey responses of 407 veterinary professionals provide quantitative evidence of how EBVM is put into practice, how EBVM is perceived to impact client behaviour and employee engagement, what the barriers are to practising EBVM and how these could be overcome. Key findings are that veterinary professionals are more likely to practise EBVM if they have been taught how to do so at vet school. EBVM is a way to provide value to and build trust with clients. Survey respondents who practise EBVM are more likely to find their workplace inspiring and to be an intellectual challenge and the main barriers to EBVM are: time and access to information. Respondents, especially those who were employees suggested overcoming these barriers through attending journal clubs and other training opportunities.

Conclusion: The study provides the view of veterinary professionals on the non-clinical benefits of EBVM, the barriers to wider implementation and ways of overcoming those barriers. Further research is needed to obtain the perspective of clients and more detailed cost effectiveness analyses could shed more light on specific practices of EBVM.

Application: Findings are applicable to universities, veterinarians and vet nurses seeking to increase the practice of EBVM. The ultimate beneficiaries are those vets who seek additional non-clinical reasons for the adoption of EBVM in their practice.

\section{INTRODUCTION}

It was revealed by a PICO-based literature review (Hauser and Jackson, 2016) that little knowledge exists about the non-clinical benefits of EBVM. It concluded that while there is some literature suggesting a link between the practice of EBVM and better non-clinical benefits such as client satisfaction and client retention, a study, focusing primarily on the non-clinical benefits of EBVM, had not yet been conducted. 
In the first stage of a two-stage process Jackson and Hauser (2017) conducted an exploratory study that found four key themes that emerged from the existing knowledge: the definition of EBVM, the benefits of EBVM, the barriers to the adoption of EBVM and ideas for exploring the broader adoption of EBVM.

This study forms the second stage of a two-part, mixed-method research project. It combined the existing knowledge from the literature (Hauser and Jackson, 2016) and the key commercial benefits of EBVM identified by Jackson and Hauser (2017) and developed a subsequent confirmatory study: an online survey comprising of 23 questions, which provides a base-line of performance and demonstrates the non-clinical benefits of EBVM. The first stage of the project clearly showed that veterinary practitioners were definite in their descriptions of other types of non-clinical benefits: increased standard of care, client satisfaction, client retention, reputation and vets' confidence. These issues were tested in the online survey as well as issues regarding the definition of EBVM, the barriers to the adoption of EBVM and the ideas practitioners have for increasing the adoption of EBVM.

This paper discusses the non-clinical benefits of EBVM by 1) defining EBVM, 2) displaying what EBVM looks like in clinical practice, 3) outlining perceived benefits to client relationships, 4) outlining benefits to employee engagement, 5) discussing the main barriers of EBVM, and 6) suggesting ways of overcoming such barriers. It is important to note that the results represent the answers of veterinary professionals, thus questions about the behaviour of other people such as clients, represent the perceived benefits of the survey participants, rather than actual benefits. Where survey participants answer for themselves, the study provides evidence of actual benefits to the veterinary profession.

\section{RESULTS}

The survey responses of 407 veterinary professionals ${ }^{1}$ provided information on the definition of EBVM and how it is put into practice, how EBVM is perceived to impact client behaviour and employee engagement, what the barriers are to practising EBVM and how these could be overcome.

\section{Characteristics}

Of the 407 survey participants $59.0 \%$ were female, $39.8 \%$ male and $1.2 \%$ did not answer the question. Respondents' age ranged from 21 to 76 years. The average age was 41.3 years, with most participants (33.0\%) being in the age group of 30 to 39 year olds. Survey participants included veterinarians (86.5\%), vet nurses $(12.8 \%)$ and students pursuing a veterinary or vet nursing degree $(0.7 \%)$. Most respondents worked with small animals $(77.8 \%)$, followed by those working in equine (8.1\%), mixed animal $(5.2 \%)$ and farm animal practices (3.7\%), and other fields (5.2\%), including academia, laboratories, exotics and practice management. The large proportion of respondents from the small animal field likely resulted due to the use of convenience sampling. Most respondents (45.3\%) stated to be working in a sub or semi urban area; this was followed by $33.5 \%$ of respondents who worked in a city and $21.2 \%$ of respondents who worked in a rural area. The majority of respondents (80.2\%) were in full time employment at the time of the survey, $17.3 \%$ were working part time, $2.0 \%$ were not employed and $0.5 \%$ preferred not to answer. Respondents were asked what best describes their current role in veterinary practice, half of all respondents were employees (50.9\%), the second largest

\footnotetext{
${ }^{1}$ Not all questions had to be answered by all respondents
} 
group were owners or joint partners (39.0\%), and $10.1 \%$ were in other working arrangements, such as locum, retired, self-employed or in academia. The veterinary professionals mainly worked in independent veterinary practice $(57.9 \%)$, corporate veterinary practice $(28.0 \%)$, academia $(8.9 \%)$ and other, which included government (5.2\%).

\section{Defining EBVM}

The following definitions of EBVM were given at the beginning of the survey: Evidence based medicine was first discussed in the human healthcare literature in the 1990s, and was defined as: "the conscientious, explicit, and judicious use of current best evidence in making decisions about the care of individual patients. The practice of evidence based medicine means integrating individual clinical expertise with the best available external clinical evidence from systematic research" (Sackett et al., 1996, p. 71).

More recently, RCVS Knowledge has adapted this definition to the provision of veterinary medicine and defines evidence based veterinary medicine (EBVM) on its web site as: "...evidence-based decisions combine clinical expertise, the most relevant and best available scientific evidence, patient circumstances and owners' values."

With these definitions in mind, survey participants were asked if they practise Evidence Based Veterinary Medicine. The choices were 'Yes', 'No' and 'Unsure'. Out of 405 respondents, 282 (69.6\%) said they practise EBVM, 16 people (4.0\%) said they did not practise EBVM and 107 respondents (26.4\%) were unsure. For the statistical analysis respondents were divided into two groups, based on whether they actively practise EBVM or not. Those who answered the question with "Yes" were considered to be actively practising EBVM, those who answered "No" or "Unsure" were considered not to be actively practising EBVM.

In order to generate evidence on how EBVM is practised by veterinary professionals, respondents were asked a range of questions about their daily practice, including about their access to publications and time and frequency of scientific research (Table 1).

Over half of all respondents (60.4\%) have access to scientific publications via platforms such as Pubmed, this is largely made up of those who actively practise EBVM compared to those who do not (Pearson Chi-Square statistic, $\chi^{2}=32.383$, and $p<0.05$ ). The result does not tell us whether those respondents who can easily access scientific publications, are also more likely to use them or whether respondents wanting to access scientific information are more likely to ensure there to be access.

Overall participants are split almost evenly into participants who have $(46.7 \%)$ and participants who have not (53.3\%) actively contributed to scientific research. There is statistically significant evidence that those who are actively practising EBVM are also more likely to have contributed to scientific research than those who are not actively practising EBVM (Pearson Chi-Square statistic, $\chi^{2}=9.734$, and $p<0.05$ ). $51.8 \%$ of those practising EBVM have also contributed to scientific research, in comparison to only $35 \%$ of respondents who are not practising EBVM.

A majority of respondents (71.6\%) do not attend journal clubs or discussion forums. However, those actively practising EBVM (36.9\%) are more likely to attend such an event than those who do not actively practise EBVM (8.9\%) (Pearson Chi-Square statistic, $\chi^{2}=32.874$, and $p<0.05$ ). 
Most survey participants have not contributed to scientific research in the past 12 months $(80.2 \%)$, however those respondents who actively practise EBVM are more likely to have contributed to scientific research in the past 12 months (23.9\%) compared to those who do not actively practise EBVM (9.9\%) (Pearson Chi-Square statistic, $\chi^{2}=10.531$, and $\left.p<0.05\right)$.

Table 1: Defining EBVM

\begin{tabular}{|c|c|c|c|c|c|}
\hline \multirow[t]{2}{*}{ Variables } & & \multicolumn{3}{|c|}{ Do you practise EBVM? } & \multirow[t]{2}{*}{ P-value $\left(\chi^{2}\right)$} \\
\hline & & Yes, N (\%) & No, $N(\%)$ & Total, N (\% o.t. $)^{2}$ & \\
\hline $\begin{array}{l}\text { Do you have access } \\
\text { to scientific } \\
\text { publications via } \\
\text { platforms (such as } \\
\text { Pubmed)? }\end{array}$ & $\begin{array}{l}\text { Yes } \\
\text { No } \\
\text { Total } \\
\text { (\% o.t.) }\end{array}$ & $\begin{array}{l}196(69.5) \\
86(30.5) \\
282(96.8)\end{array}$ & $\begin{array}{l}48(39.3) \\
74(60.7) \\
122(30.2)\end{array}$ & $\begin{array}{l}244(60.4) \\
160(39.6) \\
404(100.0)\end{array}$ & $\begin{array}{l}\chi^{2}=32.383 \\
\text { and } p<0.05\end{array}$ \\
\hline $\begin{array}{l}\text { Have you ever } \\
\text { actively contributed } \\
\text { to } \\
\text { research? }\end{array}$ & $\begin{array}{l}\text { Yes } \\
\text { No } \\
\text { Total } \\
\text { (\% o.t.) }\end{array}$ & $\begin{array}{l}147(51.8) \\
137(48.2) \\
284(69.9)\end{array}$ & $\begin{array}{l}43(35.0) \\
80(65.0) \\
123(30.2)\end{array}$ & $\begin{array}{l}190(44.7) \\
217(53.3) \\
407(100.0)\end{array}$ & $\begin{array}{l}\chi^{2}=9.734 \\
\text { and } p<0.05\end{array}$ \\
\hline $\begin{array}{l}\text { Do you attend } \\
\text { journal club(s) or any } \\
\text { type of discussion } \\
\text { forum about } \\
\text { scientific research? }\end{array}$ & $\begin{array}{l}\text { Yes } \\
\text { No } \\
\text { Total } \\
\text { (\% o.t.) }\end{array}$ & $\begin{array}{l}104(36.9) \\
178(63.1) \\
282(69.6)\end{array}$ & $\begin{array}{l}11(8.9) \\
112(91.1) \\
123(30.4)\end{array}$ & $\begin{array}{l}115(28.4) \\
290(71.6) \\
405(100.0)\end{array}$ & $\begin{array}{l}\chi^{2}=32.874 \\
\text { and } p<0.05\end{array}$ \\
\hline $\begin{array}{l}\text { Have you actively } \\
\text { contributed to } \\
\text { scientific research in } \\
\text { the past } 12 \text { months? }\end{array}$ & $\begin{array}{l}\text { Yes } \\
\text { No } \\
\text { Total } \\
\text { (\%o.t.) }\end{array}$ & $\begin{array}{l}68(23.9) \\
216(76.1) \\
284(70.1)\end{array}$ & $\begin{array}{l}12(9.9) \\
109(90.1) \\
121(29.9)\end{array}$ & $\begin{array}{l}80(19.8) \\
325(80.2) \\
405(100.0)\end{array}$ & $\begin{array}{l}\chi^{2}=10.531 \\
\text { and } p<0.05\end{array}$ \\
\hline
\end{tabular}

Most participants $(62.0 \%)$ stated that they performed the last literature search in order to influence clinical practice less than one month ago (Table 2). Those who practise EBVM were statistically more likely to have searched the literature more recently, than those who do not actively practise EBVM (Pearson Chi-Square statistic, $\chi^{2}=44.987$, and $\left.p<0.05\right)$. A much greater number of people $(26.8 \%)$ not actively practising EBVM did their last literature search to influence clinical decision making over a year ago, in comparison to only $5.3 \%$ out of those who actively practise EBVM.

Many research participants (44.3\%) spend 2-5 hours researching the literature per month (Table 2). There is statistically significant evidence that those actively practising EBVM are spending more time researching the literature, than those who are not (Pearson Chi-Square statistic, $\chi^{2}=41.493$, and $p<0.05$ ). Of the respondents who are practising EBVM, $32.2 \%$ of people spend six or more hours per month researching the literature, in

\footnotetext{
${ }^{2}$ Percentages were calculated of the total (o.t.) number of respondents. Throughout the paper, any 'apparent' discrepancies in percentages are due to rounding to one percentage point.
} 
comparison to those who do not practise EBVM, where only $14.9 \%$ spend 6 or more hours on literature research.

Table 2: Last literature search and time spent on research

\begin{tabular}{|c|c|c|c|c|c|}
\hline \multirow[t]{2}{*}{ Variables } & & \multicolumn{3}{|c|}{ Do you practise EBVM? } & \multirow[t]{2}{*}{ P-value $\left(\chi^{2}\right)$} \\
\hline & & Yes, N (\%) & No, N (\%) & Total, N (\% o.t.) & \\
\hline \multirow{7}{*}{$\begin{array}{l}\text { When did you } \\
\text { last perform a } \\
\text { literature search } \\
\text { in order to } \\
\text { influence } \\
\text { clinical practice? }\end{array}$} & Less than one & $195(69.1)$ & $56(45.5)$ & $251(62.0)$ & \multirow{7}{*}{$\begin{array}{l}\chi^{2}=44.987 \\
\text { and } p<0.05\end{array}$} \\
\hline & 1-2 months ago & $38(13.5)$ & $18(14.6)$ & $56(13.8)$ & \\
\hline & 3-6 months ago & $28(9.9)$ & $9(7.3)$ & $37(9.1)$ & \\
\hline & 7-12 months & $6(2.1)$ & $7(5.7)$ & $13(3.2)$ & \\
\hline & ago & & & & \\
\hline & Over 1 year ago & $15(5.3)$ & $33(26.8)$ & $48(11.9)$ & \\
\hline & Total (\% o.t.) & $282(69.9)$ & $\begin{array}{l}123 \\
(30.4)\end{array}$ & $405(100.0)$ & \\
\hline \multirow{8}{*}{$\begin{array}{l}\text { Approximately } \\
\text { how many } \\
\text { hours per } \\
\text { month do you } \\
\text { spend } \\
\text { researching the } \\
\text { literature? }\end{array}$} & I don't research & $10(3.5)$ & $19(15.7)$ & $29(7.2)$ & \multirow{8}{*}{$\begin{array}{l}\chi^{2}=41.493 \\
\text { and } p<0.05\end{array}$} \\
\hline & the literature & & & & \\
\hline & $\begin{array}{l}\text { Less than } 1 \text { hour } \\
\text { per month }\end{array}$ & $47(16.6)$ & $40(33.1)$ & $87(21.5)$ & \\
\hline & $\begin{array}{l}2-5 \text { hours per } \\
\text { month }\end{array}$ & $135(47.7)$ & $44(36.4)$ & $179(44.3)$ & \\
\hline & $\begin{array}{l}6-10 \text { hours per } \\
\text { month }\end{array}$ & $55(19.4)$ & $14(11.6)$ & $69(17.1)$ & \\
\hline & $\begin{array}{l}11-20 \text { hours per } \\
\text { month }\end{array}$ & $16(5.7)$ & $1(0.8)$ & $17(4.2)$ & \\
\hline & $\begin{array}{l}\text { More than } 20 \\
\text { hours } \\
\text { month }\end{array}$ & $20(7.1)$ & $3(2.5)$ & $23(5.7)$ & \\
\hline & Total (\%o.t.) & $283(70.0)$ & $\begin{array}{l}121 \\
(30.0)\end{array}$ & $404(100.0)$ & \\
\hline
\end{tabular}

\section{EBVM and clinical practice}


Most survey participants agreed $(52.0 \%)$ or strongly agreed $(25.1 \%)$ with the statement: "I practise veterinary medicine in a way that is supported by published evidence" (Table 3 ). ${ }^{3}$

Most respondents agreed (46.6\%) or strongly agreed (13.6\%) with the statement that clinical practice is based on current research. However, those respondents who do not actively practise EBVM are more likely to choose the middle ground, disagree or strongly disagree option, than those who do (Pearson Chi-Square statistic, $\chi^{2}$ $=27.664$, and $p<0.05)$.

Overall, a majority of veterinary professionals either agreed $(41.2 \%)$ or strongly agreed (16.6\%) with the statement: "Being a veterinary professional, I actively seek out opportunities to learn about EBVM". Statistically significant evidence was found that those practising EBVM are also more likely to agree with the statement (Pearson Chi-Square statistic, $\chi^{2}=39.063$, and $p<0.05$ ).

A large number of respondents either strongly disagreed (21.7\%) or disagreed (27.7\%) with the statement: "I was taught how to practise EBVM at University". The survey results provide statistically significant evidence that those who practise EBVM were also more likely to agree $(22.7 \%)$ or strongly agree $(15.5 \%)$ in comparison to those who did not (agree: $8.1 \%$, strongly agree $4.1 \%$ ) (Pearson Chi-Square statistic, $\chi^{2}=31.456$, and $p<$ $0.05)$. This finding suggests that those who were taught how to practise EBVM at university are also more likely to practise EBVM in their careers than those who did not.

Overall those who practise EBVM are more likely to consult the literature when facing a difficult case, spend more time per month researching the literature, and are more likely to contribute to scientific literature and are more likely to have done so in the past 12 months. Those who were taught how to practise EBVM at university were also more likely to practise EBVM, thus a direct link between university teaching and practising EBVM can be drawn.

\footnotetext{
${ }^{3}$ As in the collected data there are more than $20 \%$ of the contingency table cells with expected cell frequencies less than 5 , the chi-square approximation is not appropriate, thus the data cannot be analysed for statistically significant associations.
} 
Table 3: EBVM and clinical practice

\begin{tabular}{|c|c|c|c|c|c|}
\hline \multirow[t]{2}{*}{ Variables } & & \multicolumn{3}{|c|}{ Do you practise EBVM? } & \multirow[t]{2}{*}{ P-value $\left(\chi^{2}\right)$} \\
\hline & & Yes, N (\%) & No, N (\%) & Total, N (\% o.t.) & \\
\hline \multirow{6}{*}{$\begin{array}{l}\text { I practise veterinary } \\
\text { medicine in a way } \\
\text { that is supported by } \\
\text { published evidence }\end{array}$} & $\begin{array}{l}\text { Strongly } \\
\text { Disagree }\end{array}$ & $0(0.0)$ & $0(0.0)$ & $0(0.0)$ & $\begin{array}{l}\chi^{2}=86.136 \\
\text { and } p<0.05^{*}\end{array}$ \\
\hline & Disagree & $0(0.0)$ & $5(4.1)$ & $5(1.2)$ & \\
\hline & $\begin{array}{l}\text { Middle } \\
\text { Ground }\end{array}$ & $32(11.3)$ & $56(45.5)$ & $88(21.7)$ & \\
\hline & Agree & $156(55.1)$ & $55(44.7)$ & $211(52.0)$ & \\
\hline & $\begin{array}{l}\text { Strongly } \\
\text { Agree }\end{array}$ & 95 (33.6) & $7(5.7)$ & $102(25.1)$ & \\
\hline & $\begin{array}{l}\text { Total } \quad(\% \\
\text { o.t. })\end{array}$ & $283(69.7)$ & $123(30.3)$ & 406 (100.0) & \\
\hline \multirow{9}{*}{$\begin{array}{l}\text { Clinical practice is } \\
\text { based on current } \\
\text { research }\end{array}$} & Strongly & $2(0.7)$ & $2(1.6)$ & $4(1.0)$ & $\chi^{2}=21.791$ \\
\hline & Disagree & & & & and $p<0.05$ \\
\hline & Disagree & $16(5.7)$ & $13(10.7)$ & $29(7.2)$ & \\
\hline & Middle & $78(27.6)$ & $51(41.8)$ & 129 (31.9) & \\
\hline & Ground & & & & \\
\hline & Agree & $134(47.3)$ & $54(44.3)$ & $188(46.4)$ & \\
\hline & Strongly & $53(18.7)$ & $2(1.6)$ & $55(13.6)$ & \\
\hline & Agree & & & & \\
\hline & $\begin{array}{l}\text { Total } \quad(\% \\
\text { o.t. })\end{array}$ & 283 (69.9) & 122 (30.1) & 405 (100.0) & \\
\hline \multirow{10}{*}{$\begin{array}{l}\text { Being a veterinary } \\
\text { professional, } \\
\text { actively seek out } \\
\text { opportunities to } \\
\text { learn about EBVM }\end{array}$} & Strongly & $1(0.4)$ & $4(3.3)$ & $5(1.2)$ & $\chi^{2}=39.063$ \\
\hline & Disagree & & & & and $p<0.05$ \\
\hline & Disagree & $18(6.4)$ & $19(15.6)$ & $37(9.2)$ & \\
\hline & & & & & \\
\hline & Middle & 77 (27.4) & $51(41.8)$ & 128 (31.8) & \\
\hline & Ground & & & & \\
\hline & Agree & $122(43.4)$ & $44(36.1)$ & 166 (41.2) & \\
\hline & Strongly & $63(22.4)$ & $4(3.3)$ & $67(16.6)$ & \\
\hline & Agree & & & & \\
\hline & Total & 281 (69.7) & $122(30.3)$ & 403 (100.0) & \\
\hline \multirow{5}{*}{$\begin{array}{l}\text { I was taught how to } \\
\text { practise EBVM at } \\
\text { university }\end{array}$} & $\begin{array}{l}\text { Strongly } \\
\text { Disagree }\end{array}$ & $47(16.9)$ & $40(32.5)$ & $87(21.7)$ & $\begin{array}{l}\chi^{2}=31.456 \\
\text { and } p<0.05\end{array}$ \\
\hline & Disagree & $69(24.8)$ & $42(34.1)$ & $111(27.7)$ & \\
\hline & Middle & $56(20.1)$ & $26(21.1)$ & $82(20.4)$ & \\
\hline & Ground & & & & \\
\hline & Agree & $63(22.7)$ & $10(8.1)$ & $73(18.2)$ & \\
\hline
\end{tabular}




\begin{tabular}{lllll}
\hline Variables & \multicolumn{3}{c}{ Do you practise EBVM? } & P-value $\left(\chi^{2}\right)$ \\
\cline { 2 - 4 } & & Yes, N (\%) & No, N (\%) & Total, N (\% o.t.) \\
\hline $\begin{array}{l}\text { Strongly } \\
\text { Agree }\end{array}$ & $43(15.5)$ & $5(4.1)$ & $48(12.0)$ \\
& & & \\
Total & $278(69.3)$ & $123(30.7)$ & $40100.0)$ \\
& & & \\
\hline
\end{tabular}

*As in the collected data there are more than $20 \%$ of the contingency table cells with expected cell frequencies less than 5 , the chi-square approximation is not appropriate, thus the data cannot be analysed for statistically significant associations.

\section{Understanding the benefits of EBVM}

In the following section respondents were asked about their understanding of the benefits of EBVM. It was also tested if there is a significant association between those who do and those who do not actively practise EBVM and the responses given to the survey questions.

The majority of survey participants agreed or strongly agreed (76.4\%) with the statement: "Clients are unaware of EBVM" (Table 4). Interestingly those who do not practise EBVM are significantly more likely to strongly agree $(48.0 \%)$, than those who do practise EBVM (28.0\%) (Pearson Chi-Square statistic, $\chi^{2}$ $=21.791$, and $p<0.05$ ).

Those veterinary professionals who practise EBVM were more likely to agree or strongly agree with the statement: "EBVM helps overcome the unknown", than those who did not (Pearson Chi-Square statistic, $\chi^{2}$ $=10.212$, and $p<0.05)$. Interestingly even out of those not practising EBVM, a large number of people either agreed $(52.8 \%)$ or strongly agreed $(14.6 \%)$ with the statement. Out of the same group, only $8.9 \%$ disagreed and $2.4 \%$ strongly disagreed with the statement. This finding suggests that also those not practising EBVM believe it to be a good practice to help overcome the unknown, however there are other barriers to implementation.

Many respondents either agreed $(50.1 \%)$ or strongly agreed $(23.8 \%)$ with the following statement: "Clients appreciate when I put in extra work researching their specific case". No significant difference in associations was found between the two groups.

Over $63.6 \%$ of all respondents agreed or strongly agreed with the statement that practising EBVM provides the best value to the customer. Even of those not practising EBVM, only $8.4 \%$ of people disagree and $1.7 \%$ strongly disagree with the statement. This further suggests that even though the non-clinical benefits of EBVM are perceived even by those who do not practice it, there are some barriers to the adoption of EBVM, that still outweigh those perceived benefits. There is a statistically significant difference in associations between the two groups significant (Pearson Chi-Square statistic, $\chi^{2}=30.283$, and $p<0.05$ ). 
Table 4: Perceived benefits to the client I

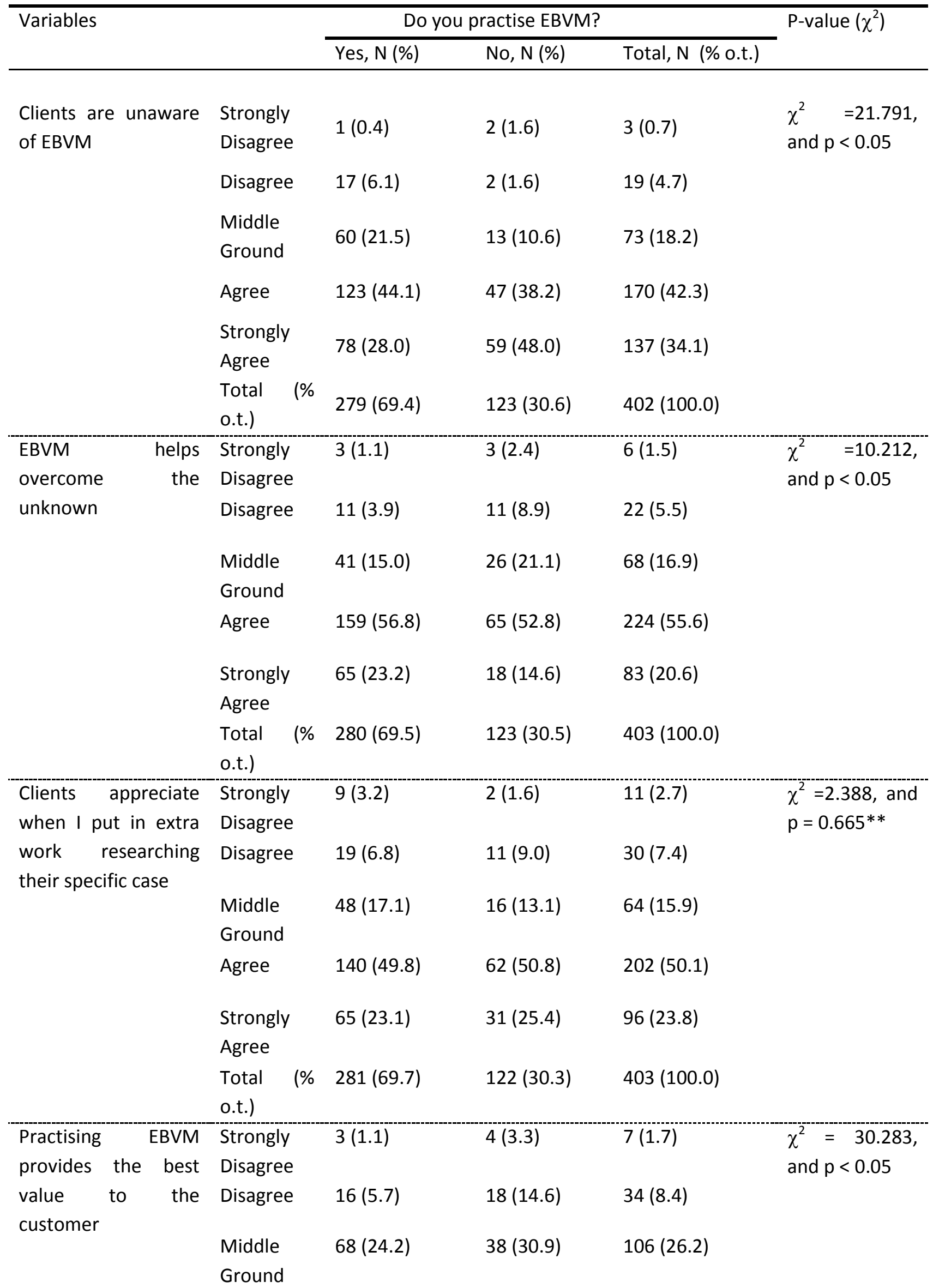




\begin{tabular}{|c|c|c|c|c|c|}
\hline \multirow[t]{2}{*}{ Variables } & & \multicolumn{3}{|c|}{ Do you practise EBVM? } & \multirow[t]{2}{*}{ P-value $\left(\chi^{2}\right)$} \\
\hline & & Yes, N (\%) & No, N (\%) & Total, N (\% o.t.) & \\
\hline & Agree & $120(42.7)$ & $56(45.5)$ & $176(43.6)$ & \\
\hline & Strongly & $74(26.3)$ & $7(5.7)$ & $81(20.0)$ & \\
\hline & Agree & & & & \\
\hline & $\begin{array}{l}\text { Total } \quad \text { (\% } \\
\text { o.t.) }\end{array}$ & $281(69.6)$ & $123(30.4)$ & $404(100.0)$ & \\
\hline
\end{tabular}

** No significant difference in association was found between the groups

As shown in Table 5, the majority of respondents agreed (47.9\%) or strongly agreed (14.4\%) with the following statement: "Practising EBVM builds trust with clients". Those who practise EBVM were statistically more likely to strongly agree with the statement in comparison to those who do not practise EBVM (Pearson Chi-Square statistic, $\chi^{2}=29.827$, and $p<0.05$ ).

The findings also show that many respondents $(40.7 \%)$ chose the middle ground on the question whether EBVM provides a competitive advantage over other practices. While the responses between the two groups do statistically differ (Pearson Chi-Square statistic, $\chi^{2}=28.027$, and $p<0.05$ ), the important finding is, that overall respondents are either choosing the middle ground $(40.7 \%)$, agree $(30.1 \%)$ or strongly agree $(11.6 \%)$. While those who actively practise EBVM are more likely to agree or strongly agree with the statement, the interesting finding is here, that also those who do not actively practise EBVM believe there to be a competitive advantage.

Most respondents (42.4\%) chose the middle ground option to the question: "Clients appreciate an evidence based approach". While survey participants who actively practise EBVM were more likely to agree or strongly agree with the statement than those who do not (Pearson Chi-Square statistic, $\chi^{2}=23.391$, and $p<0.05$ ), there does not seem to be a consensus about whether clients appreciate an evidence-based approach. 
Table 5: Perceived benefits to the client II

\begin{tabular}{|c|c|c|c|c|c|}
\hline \multirow[t]{2}{*}{ Variables } & & \multicolumn{3}{|c|}{ Do you practise EBVM? } & \multirow[t]{2}{*}{ P-value $\left(\chi^{2}\right)$} \\
\hline & & Yes, N (\%) & No, N (\%) & Total, N (\% o.t.) & \\
\hline \multirow{9}{*}{$\begin{array}{l}\text { Practising } \\
\text { builds trust } \\
\text { clients }\end{array}$} & Strongly & $1(0.4)$ & $2(1.6)$ & $3(0.7)$ & $\chi^{2}=30.283$, \\
\hline & Disagree & & & & and $p<0.05$ \\
\hline & Disagree & $9(3.2)$ & $16(13.0)$ & $25(6.2)$ & \\
\hline & Middle & $80(28.6)$ & $44(35.8)$ & $124(30.8)$ & \\
\hline & Ground & & & & \\
\hline & Agree & 137 (48.9) & $56(45.5)$ & $193(47.9)$ & \\
\hline & Strongly & 53 (18.9) & $5(4.1)$ & $58(14.4)$ & \\
\hline & Agree & & & & \\
\hline & $\begin{array}{l}\text { Total } \quad(\% \\
\text { o.t. })\end{array}$ & $280(69.5)$ & $123(30.5)$ & $403(100.0)$ & \\
\hline \multirow{6}{*}{$\begin{array}{l}\text { Practising } \\
\text { provides } \\
\text { competitive } \\
\text { advantage } \\
\text { other practice }\end{array}$} & $\begin{array}{l}\text { Strongly } \\
\text { Disagree }\end{array}$ & $3(1.1)$ & $4(3.3)$ & $7(1.7)$ & $\begin{array}{l}\chi^{2}=28.027 \\
\text { and } p<0.05\end{array}$ \\
\hline & Disagree & $31(11.0)$ & $33(26.8)$ & $64(15.8)$ & \\
\hline & $\begin{array}{l}\text { Middle } \\
\text { Ground }\end{array}$ & $114(40.4)$ & $51(41.5)$ & $165(40.7)$ & \\
\hline & Agree & $91(32.3)$ & $31(25.2)$ & $122(30.1)$ & \\
\hline & $\begin{array}{l}\text { Strongly } \\
\text { Agree }\end{array}$ & $43(15.2)$ & $4(3.3)$ & $47(11.6)$ & \\
\hline & $\begin{array}{ll}\text { Total } & (\% \\
\text { o.t. }) & \end{array}$ & $282(69.6)$ & $123(30.4)$ & $405(100.0)$ & \\
\hline \multirow{9}{*}{$\begin{array}{l}\text { Clients appreciate an } \\
\text { evidence based } \\
\text { approach }\end{array}$} & Strongly & $5(1.8)$ & $6(4.9)$ & $11(2.7)$ & $\chi^{2}=23.391$, \\
\hline & Disagree & & & & and $p<0.05$ \\
\hline & Disagree & $32(11.5)$ & $32(26.2)$ & $64(16.0)$ & \\
\hline & Middle & $121(43.4)$ & $49(40.2)$ & $170(42.4)$ & \\
\hline & Ground & & & & \\
\hline & Agree & $100(35.8)$ & 34 (27.9) & $134(33.4)$ & \\
\hline & Strongly & $21(7.5)$ & $1(0.8)$ & $22(5.5)$ & \\
\hline & Agree & & & & \\
\hline & $\begin{array}{l}\text { Total } \quad(\% \\
\text { o.t. })\end{array}$ & 279 (69.9) & $122(30.4)$ & $401(100.0)$ & \\
\hline
\end{tabular}

The study does not provide conclusive evidence on whether veterinary professionals believe that EBVM saves the client money (Table 6). There was no significant difference in the responses between those who do and do not actively practise EBVM. Most survey participants (44.6\%) chose the middle ground on this answer. Interestingly out of those respondents who do not practise EBVM about as many people disagreed (23.6\%) 
with the statement as agreed (22.8\%). This result is not surprising, as the practice of EBVM, does not necessarily always favour the cheapest option and is sometimes associated with spending more time and money on diagnostics.

The study finds no conclusive evidence that clients are more invested in treatment choice through EBVM. Many respondents (49.8\%) chose the middle ground option, this could be based on the underlying assumption that clients are unaware of EBVM. There is statistically significant evidence that those survey participants practising EBVM were more likely to agree or strongly agree that clients are more invested in treatment choice through EBVM, than those who do not (Pearson Chi-Square statistic, $\chi^{2}=12.447$, and $p<0.05$ ).

Overall respondents either strongly disagree or disagree (37.6\%), chose the middle ground $(35.6 \%)$ or where slightly less likely to agree or strongly agree (26.7\%) on the statement: "Clients are less likely to seek out a different practice if they know a vet is practising EBVM". Survey participants who practise EBVM were more likely to agree or strongly agree that clients are less likely to go to a different practice than those who do not practise EBVM (Pearson Chi-Square statistic, $\chi^{2}=16.950$, and $p<0.05$ ).

Table 6: Perceived benefits to the client III

\begin{tabular}{|c|c|c|c|c|c|}
\hline \multirow[t]{2}{*}{ Variables } & & \multicolumn{3}{|c|}{ Do you practise EBVM? } & \multirow[t]{2}{*}{ P-value $\left(\chi^{2}\right)$} \\
\hline & & Yes, N (\%) & No, N (\%) & Total, N (\% o.t.) & \\
\hline \multirow{9}{*}{$\begin{array}{l}\text { Practising EBVM } \\
\text { saves the client } \\
\text { money }\end{array}$} & Strongly & $4(1.4)$ & $5(4.1)$ & $9(2.2)$ & \multirow{9}{*}{$\begin{array}{l}\chi^{2}=8.162, \text { and } \\
p=0.086^{* *}\end{array}$} \\
\hline & Disagree & & & & \\
\hline & Disagree & $50(17.8)$ & $29(23.6)$ & 79 (19.6) & \\
\hline & Middle & $123(43.8)$ & $57(46.3)$ & $180(44.6)$ & \\
\hline & Ground & & & & \\
\hline & Agree & $83(29.5)$ & $28(22.8)$ & $111(27.5)$ & \\
\hline & Strongly & $21(7.5)$ & $4(3.3)$ & $25(6.2)$ & \\
\hline & Agree & & & & \\
\hline & $\begin{array}{l}\text { Total } \quad(\% \\
\text { o.t. })\end{array}$ & $281(69.6)$ & $123(30.4)$ & $404(100.0)$ & \\
\hline \multirow{6}{*}{$\begin{array}{l}\text { Clients are more } \\
\text { invested in the } \\
\text { treatment choice } \\
\text { through EBVM }\end{array}$} & $\begin{array}{l}\text { Strongly } \\
\text { Disagree }\end{array}$ & $6(2.1)$ & $4(3.3)$ & $10(2.5)$ & \multirow[t]{6}{*}{$\begin{array}{l}\chi^{2}=12.447 \\
\text { and } p<0.05\end{array}$} \\
\hline & Disagree & $47(16.8)$ & $26(21.3)$ & $73(18.2)$ & \\
\hline & $\begin{array}{l}\text { Middle } \\
\text { Ground }\end{array}$ & $131(46.8)$ & 69 (56.6) & $200(49.8)$ & \\
\hline & Agree & $83(29.6)$ & $23(18.9)$ & $106(26.4)$ & \\
\hline & $\begin{array}{l}\text { Strongly } \\
\text { Agree }\end{array}$ & $13(4.6)$ & $0(0.0)$ & $13(3.2)$ & \\
\hline & $\begin{array}{l}\text { Total } \quad(\% \\
\text { o.t. })\end{array}$ & $280(69.7)$ & $122(30.3)$ & $402(100.0)$ & \\
\hline $\begin{array}{l}\text { Clients are less likely } \\
\text { to seek out a }\end{array}$ & $\begin{array}{l}\text { Strongly } \\
\text { Disagree }\end{array}$ & $17(6.0)$ & $10(8.1)$ & $27(6.7)$ & $=16.950$, \\
\hline
\end{tabular}




\begin{tabular}{|c|c|c|c|c|c|}
\hline \multirow[t]{2}{*}{ Variables } & & \multicolumn{3}{|c|}{ Do you practise EBVM? } & \multirow[t]{2}{*}{ P-value $\left(\chi^{2}\right)$} \\
\hline & & Yes, N (\%) & No, N (\%) & Total, N (\% o.t.) & \\
\hline \multirow{6}{*}{$\begin{array}{l}\text { different practice if } \\
\text { they know a vet is } \\
\text { practicing EBVM }\end{array}$} & Disagree & $72(25.6)$ & $53(43.1)$ & $125(30.9)$ & and $p<0.05$ \\
\hline & $\begin{array}{l}\text { Middle } \\
\text { Ground }\end{array}$ & $106(37.7)$ & $38(30.9)$ & $144(35.6)$ & \\
\hline & Agree & $61(21.7)$ & $19(15.4)$ & $80(19.8)$ & \\
\hline & Strongly & $25(8.9)$ & $3(2.4)$ & $28(6.9)$ & \\
\hline & Agree & & & & \\
\hline & $\begin{array}{ll}\text { Total } & (\% \\
\text { o.t. }) & \end{array}$ & 281 (69.9) & $123(30.4)$ & $404(100.0)$ & \\
\hline
\end{tabular}

** No significant difference in association was found between the groups

\subsection{Understanding EBVM and employee engagement}

Participants were asked questions about EBVM and employee engagement, which included questions about the impact of EBVM on confidence in decision making and provision of best care for the patient.

As shown in Table 7, the clear majority of respondents either agreed (47.8\%) or strongly agreed (40.6\%) with the following statement: "Practising EBVM makes me feel like I have provided the best medical care for my patient" ${ }^{\prime \prime}$. Most veterinary professionals either agree or strongly agree (83.4\%) with the following statement: "EBVM gives me more confidence in clinical decision making". ${ }^{5}$ Most respondents agree (48.3\%) or strongly agree (31.9\%) with the statement: "I frequently share research and clinical experience with colleagues". ${ }^{6}$

Most respondents agree (43.5\%) or strongly agree (25.8\%) with the statement: "Practising EBVM provides me with an inspiring, intellectual challenge to my job as a vet". Those practising EBVM are more likely to find EBVM an inspiring and intellectual challenge, than those who do not (Pearson Chi-Square statistic, $\chi^{2}=47.645$, and $p<0.05)$.

These are arguably the most important findings of this research as they suggest that the practice of EBVM can be viewed as a powerful tool for greater employee engagement, specifically when attracting early career veterinary professionals. Further research could be conducted to measure the importance of being able to practice EBVM in comparison to other factors playing a role in a vet's decision to choose a practice for satisfying employment.

\footnotetext{
${ }^{4,5,6}$ As in the collected data there are more than $20 \%$ of the contingency table cells with expected cell frequencies less than 5 , the chi-square approximation is not appropriate, thus the data cannot be analysed for statistically significant associations.
} 
Table 7: EBVM and employee engagement

\begin{tabular}{|c|c|c|c|c|c|}
\hline \multirow[t]{2}{*}{ Variables } & & \multicolumn{3}{|c|}{ Do you practise EBVM? } & \multirow[t]{2}{*}{ P-value $\left(\chi^{2}\right)$} \\
\hline & & Yes, N (\%) & No, N (\%) & Total, N (\% o.t.) & \\
\hline \multirow{10}{*}{$\begin{array}{l}\text { Practising EBVM } \\
\text { makes me feel like I } \\
\text { have provided the } \\
\text { best medical care for } \\
\text { my patient }\end{array}$} & Strongly & $0(0.0)$ & $1(0.8)$ & $1(0.2)$ & $\chi^{2}=37.011$ \\
\hline & Disagree & & & & and $p<0.05^{*}$ \\
\hline & Disagree & $0(0.0)$ & $5(4.1)$ & $5(1.2)$ & \\
\hline & Middle & $19(6.8)$ & $17(13.8)$ & $36(8.9)$ & \\
\hline & Ground & & & & \\
\hline & Agree & $127(45.2)$ & $66(53.7)$ & $193(47.8)$ & \\
\hline & Strongly & $134(47.7)$ & $30(24.4)$ & $164(40.6)$ & \\
\hline & Agree & & & & \\
\hline & $\begin{array}{l}\text { Not } \\
\text { applicable }\end{array}$ & $1(0.4)$ & $4(3.3)$ & $5(1.2)$ & \\
\hline & $\begin{array}{ll}\text { Total } & (\% \\
\text { o.t. }) & \end{array}$ & 281 (69.9) & $123(30.4)$ & $404(100.0)$ & \\
\hline \multirow{7}{*}{$\begin{array}{l}\text { EBVM gives me more } \\
\text { confidence in clinical } \\
\text { decision making }\end{array}$} & $\begin{array}{l}\text { Strongly } \\
\text { Disagree }\end{array}$ & $0(0.0)$ & $1(0.8)$ & $1(0.2)$ & $\begin{array}{l}\chi^{2}=37.068 \\
\text { and } p<0.05^{*}\end{array}$ \\
\hline & Disagree & $2(0.7)$ & $4(3.3)$ & $6(1.5)$ & \\
\hline & $\begin{array}{l}\text { Middle } \\
\text { Ground }\end{array}$ & $28(10.0)$ & $26(21.1)$ & $54(13.4)$ & \\
\hline & Agree & $127(45.4)$ & $68(55.3)$ & $195(48.4)$ & \\
\hline & $\begin{array}{l}\text { Strongly } \\
\text { Agree }\end{array}$ & $121(43.2)$ & $20(16.3)$ & $141(35.0)$ & \\
\hline & $\begin{array}{l}\text { Not } \\
\text { applicable }\end{array}$ & $2(0.7)$ & $4(3.3)$ & $6(1.5)$ & \\
\hline & $\begin{array}{l}\text { Total } \quad(\% \\
\text { o.t. })\end{array}$ & $280(69.5)$ & $123(30.5)$ & $403(100.0)$ & \\
\hline \multirow{9}{*}{$\begin{array}{l}\text { I frequently share } \\
\text { research and clinical } \\
\text { experience with } \\
\text { colleagues }\end{array}$} & $\begin{array}{l}\text { Strongly } \\
\text { Disagree }\end{array}$ & $2(0.7)$ & $1(0.8)$ & $3(0.7)$ & $\begin{array}{l}\chi^{2}=41.589, \\
\text { and } p<0.05^{*}\end{array}$ \\
\hline & Disagree & $10(3.6)$ & $15(12.2)$ & $25(6.2)$ & \\
\hline & Middle & $27(9.6)$ & $18(14.6)$ & $45(11.1)$ & \\
\hline & Ground & & & & \\
\hline & Agree & 129 (45.9) & $66(53.7)$ & $195(48.3)$ & \\
\hline & Strongly & $112(39.9)$ & $17(13.8)$ & $129(31.9)$ & \\
\hline & Agree & & & & \\
\hline & $\begin{array}{l}\text { Not } \\
\text { applicable }\end{array}$ & $1(0.4)$ & $6(4.9)$ & $7(1.7)$ & \\
\hline & $\begin{array}{ll}\text { Total } & (\% \\
\text { o.t. }) & \end{array}$ & $281(69.5)$ & $123(30.4)$ & $404(100.0)$ & \\
\hline
\end{tabular}




\begin{tabular}{|c|c|c|c|c|c|}
\hline \multirow[t]{2}{*}{ Variables } & & \multicolumn{3}{|c|}{ Do you practise EBVM? } & \multirow[t]{2}{*}{ P-value $\left(\chi^{2}\right)$} \\
\hline & & Yes, N (\%) & No, N (\%) & Total, N (\% o.t.) & \\
\hline \multirow{8}{*}{$\begin{array}{l}\text { Practising EBVM } \\
\text { provides me with an } \\
\text { inspiring, intellectual } \\
\text { challenge to my job } \\
\text { as a vet }\end{array}$} & Strongly & $1(0.4)$ & $2(1.7)$ & $3(0.8)$ & \multirow{8}{*}{$\begin{aligned} \chi^{2} & =47.645 \\
\text { and } p & <0.05\end{aligned}$} \\
\hline & Disagree & $9(3.2)$ & $10(8.3)$ & $19(4.8)$ & \\
\hline & $\begin{array}{l}\text { Middle } \\
\text { Ground }\end{array}$ & $38(13.6)$ & $44(36.4)$ & $82(20.5)$ & \\
\hline & Agree & $127(45.5)$ & $47(38.8)$ & $174(43.5)$ & \\
\hline & Strongly & $92(33.0)$ & $11(9.1)$ & $103(25.8)$ & \\
\hline & Agree & & & & \\
\hline & $\begin{array}{l}\text { Not } \\
\text { applicable }\end{array}$ & $12(4.3)$ & $7(5.8)$ & $19(4.8)$ & \\
\hline & $\begin{array}{ll}\text { Total } & (\% \\
\text { o.t. }) & \end{array}$ & $279(69.8)$ & $121(30.3)$ & $400(100.0)$ & \\
\hline
\end{tabular}

${ }^{*}$ As in the collected data there are more than $20 \%$ of the contingency table cells with expected cell frequencies less than 5 , the chi-square approximation is not appropriate, thus the data cannot be analysed for statistically significant associations.

\section{The barriers to EBVM}

Participants were asked to share their opinion on barriers to using EBVM.

Overall most survey participants agreed (43.7) or strongly agreed (23.8) that clinical practice is often based on anecdotal evidence (Table 8). This suggests that there is scope to expand EBVM further. There was no significant association between the practice of EBVM and the answer to the question of whether clinical practice is based on anecdotal evidence.

Many respondents agreed $(43.1 \%)$ or strongly agreed $(17.0 \%)$ with the following statement: "There is not enough time to practise EBVM. Those not practising EBVM tended to select the "strongly agree" more often (26.2\%), than those who do (12.9\%) (Pearson Chi-Square statistic, $\chi^{2}=17.607$, and $p<0.05$ ).

Only $17.9 \%$ of respondents disagreed with the statement that information is not freely available. No significant difference in associations was found between the groups. This finding thus suggests that availability of information is a key barrier to practising EBVM. 
Table 8: The barriers to EBVM I

\begin{tabular}{|c|c|c|c|c|c|}
\hline \multirow[t]{2}{*}{ Variables } & & \multicolumn{3}{|c|}{ Do you practise EBVM? } & \multirow[t]{2}{*}{ P-value $\left(\chi^{2}\right)$} \\
\hline & & Yes, N (\%) & No, N (\%) & Total, N (\% o.t.) & \\
\hline \multirow{10}{*}{$\begin{array}{l}\text { Clinical practice is } \\
\text { often based on } \\
\text { anecdotal evidence }\end{array}$} & Strongly & $0(0.0)$ & $0(0.0)$ & $0(0.0)$ & $\chi^{2}=2.804$, and \\
\hline & Disagree & & & & $p=0.423 * *$ \\
\hline & Disagree & $30(10.7)$ & $8(6.6)$ & $38(9.4)$ & \\
\hline & Middle & $66(23.5)$ & $27(22.1)$ & $93(23.1)$ & \\
\hline & Ground & & & & \\
\hline & Agree & $123(43.8)$ & $53(43.4)$ & $176(43.7)$ & \\
\hline & Strongly & $62(22.1)$ & 34 (27.9) & $96(23.8)$ & \\
\hline & Agree & & & & \\
\hline & Total $\quad(\%$ & 281 (69.7) & $122(30.3)$ & 403 (100.0) & \\
\hline & o.t.) & & & & \\
\hline \multirow{6}{*}{$\begin{array}{l}\text { There is not enough } \\
\text { time to practise } \\
\text { EBVM }\end{array}$} & $\begin{array}{l}\text { Strongly } \\
\text { Disagree }\end{array}$ & $3(1.1)$ & $0(0.0)$ & $3(0.7)$ & $\begin{array}{l}\chi^{2} \quad=17.607 \\
\text { and } p<0.05\end{array}$ \\
\hline & Disagree & $51(18.3)$ & $9(7.4)$ & $60(15.0)$ & \\
\hline & $\begin{array}{l}\text { Middle } \\
\text { Ground }\end{array}$ & $65(23.2)$ & $32(26.2)$ & $97(24.2)$ & \\
\hline & Agree & $124(44.4)$ & $49(40.2)$ & $173(43.1)$ & \\
\hline & $\begin{array}{l}\text { Strongly } \\
\text { Agree }\end{array}$ & 36 (12.9) & $32(26.2)$ & $68(17.0)$ & \\
\hline & $\begin{array}{l}\text { Total } \quad(\% \\
\text { o.t. }) \quad\end{array}$ & 279 (69.6) & $122(30.4)$ & 401 (100.0) & \\
\hline \multirow{10}{*}{$\begin{array}{l}\text { Information is not } \\
\text { freely available }\end{array}$} & Strongly & $4(1.4)$ & $1(0.8)$ & $5(1.2)$ & $\chi^{2}=5.701$, and \\
\hline & Disagree & & & & $p=0.223^{* *}$ \\
\hline & Disagree & $55(19.6)$ & $17(13.9)$ & 72 (17.9) & \\
\hline & Middle & $63(22.5)$ & $25(20.5)$ & 88 (31.9) & \\
\hline & Ground & & & & \\
\hline & Agree & 105 (37.5) & $44(36.1)$ & 149 (37.1) & \\
\hline & Strongly & 53 (18.9) & $35(28.7)$ & 88 (21.9) & \\
\hline & Agree & & & & \\
\hline & Total $\quad(\%$ & $280(69.7)$ & $122(30.3)$ & 402 (100.0) & \\
\hline & o.t.) & & & & \\
\hline
\end{tabular}

** No significant difference in association was found between the groups 
As shown in Table 9, most respondents chose the middle ground (30\%) or agree (38.6\%) option on the following question: "Clients do not want lengthy, diagnosis laden treatment options." Statistically, those not practising EBVM are more likely to agree $(40.7 \%)$ or strongly agree $(23.6 \%)$ with the statement than those who do not (Pearson Chi-Square statistic, $\chi^{2}=18.937$, and $p<0.05$ ).

The study provides no clear indication on the quality of evidence. Those who practise EBVM are more likely to disagree $(21.9 \%)$ or strongly disagree $(1.4 \%)$ with the statement: "The evidence available is often of low quality" (Pearson Chi-Square statistic, $\chi^{2}=12.227$, and $p<0.05$ ). However, there were a large number of veterinary professionals who were undecided $(32.2 \%)$, thus no clear statement can be made on the perceived quality of information available.

Over half (50.5\%) of survey participants chose the middle ground on the question of whether eminence based veterinary medicine is taught at vet schools. This finding is likely to suggest that higher educational institutions provide a mix of eminence and evidence-based veterinary teaching, differing based individual courses and teaching staff. No significant difference in associations was found between the two groups. 
Table 9: The barriers to EBVM II

\begin{tabular}{|c|c|c|c|c|c|}
\hline \multirow[t]{2}{*}{ Variables } & & \multicolumn{3}{|c|}{ Do you practise EBVM? } & \multirow[t]{2}{*}{ P-value $\left(\chi^{2}\right)$} \\
\hline & & Yes, N (\%) & No, N (\%) & Total, N (\% o.t.) & \\
\hline \multirow{10}{*}{$\begin{array}{l}\text { Clients do not want } \\
\text { lengthy, diagnosis } \\
\text { laden } \\
\text { options }\end{array}$} & Strongly & $5(1.8)$ & $0(0.0)$ & $5(1.2)$ & $\chi^{2}=18.937$ \\
\hline & Disagree & & & & and $p<0.05$ \\
\hline & Disagree & $53(18.9)$ & $12(9.8)$ & $65(16.1)$ & \\
\hline & Middle & $89(31.7)$ & $32(26.0)$ & $121(30.0)$ & \\
\hline & Ground & & & & \\
\hline & Agree & $106(37.7)$ & $50(40.7)$ & $156(38.6)$ & \\
\hline & Strongly & $28(10.0)$ & $29(23.6)$ & $57(14.1)$ & \\
\hline & Agree & & & & \\
\hline & Total $\quad(\%$ & $281(69.6)$ & $123(30.4)$ & 404 (100.0) & \\
\hline & o.t.) & & & & \\
\hline \multirow{7}{*}{$\begin{array}{l}\text { The evidence } \\
\text { available is often of } \\
\text { low quality }\end{array}$} & Strongly & $4(14)$ & (ח) & $4(10)$ & $\chi^{2}=12.227$ \\
\hline & Disagree & & & & and $p<0.05$ \\
\hline & Disagree & 61 (21.9) & $16(13.1)$ & $77(19.2)$ & \\
\hline & $\begin{array}{l}\text { Middle } \\
\text { Ground }\end{array}$ & $81(29.0)$ & $48(39.3)$ & $129(32.2)$ & \\
\hline & Agree & $98(35.1)$ & 34 (27.9) & $132(32.9)$ & \\
\hline & $\begin{array}{l}\text { Strongly } \\
\text { Agree }\end{array}$ & $35(12.5)$ & $24(19.7)$ & $59(14.7)$ & \\
\hline & $\begin{array}{l}\text { Total } \quad(\% \\
\text { o.t. })\end{array}$ & $279(69.6)$ & $122(30.4)$ & $401(100.0)$ & \\
\hline \multirow{8}{*}{$\begin{array}{l}\text { Eminence based } \\
\text { veterinary medicine } \\
\text { is taught at vet } \\
\text { schools }\end{array}$} & $\begin{array}{l}\text { Strongly } \\
\text { Disagree }\end{array}$ & $9(3.3)$ & $5(4.2)$ & $14(3.6)$ & $\begin{array}{l}\chi^{2}=0.905, \text { and } \\
p=0.924^{* *}\end{array}$ \\
\hline & Disagree & $32(11.7)$ & $13(10.8)$ & $45(11.4)$ & \\
\hline & Middle & $137(50.0)$ & $62(51.7)$ & $199(50.5)$ & \\
\hline & Ground & & & & \\
\hline & Agree & $79(28.8)$ & $35(29.2)$ & 114 (28.9) & \\
\hline & Strongly & $17(6.2)$ & $5(4.2)$ & $22(5.6)$ & \\
\hline & Agree & & & & \\
\hline & $\begin{array}{l}\text { Total } \quad(\% \\
\text { o.t. })\end{array}$ & 274 (69.5) & $120(30.5)$ & $394(100.0)$ & \\
\hline
\end{tabular}

** No significant difference in association was found between the groups

Table 10 shows that most respondents did not agree (48\%) with the following statement: "Application of EBVM ignores clinical experience." This suggests that the perception of EBVM undermining a veterinarian's clinical experience is only perceived as a barrier by a minority of vets. Those who practise EBVM are more 
likely to disagree or strongly disagree than those who do not (Pearson Chi-Square statistic, $\chi^{2}=13.947$, and $p<$ 0.05).

Interestingly only $9.6 \%$ of respondents agreed or strongly agreed with the statement that EBVM is impractical. This suggests that impracticality is not perceived to be a barrier to practising EBVM by most survey respondents. As highlighted in Table 10, those practising EBVM were more likely to disagree or disagree strongly than those who do not (Pearson Chi-Square statistic, $\chi^{2}=37.886$, and $p<0.05$ ).

Survey respondents disagreed $(49.7 \%)$ or strongly disagreed (14.6\%) with the statement that through EBVM their clinical autonomy is lost or reduced. Those who practice EBVM were statistically more likely to disagree than those not practising EBVM (Pearson Chi-Square statistic, $\chi^{2}=17.988$, and $p<0.05$ ).

Table 10: The barriers to EBVM III

\begin{tabular}{|c|c|c|c|c|c|}
\hline \multirow[t]{2}{*}{ Variables } & & \multicolumn{3}{|c|}{ Do you practise EBVM? } & \multirow[t]{2}{*}{ P-value $\left(\chi^{2}\right)$} \\
\hline & & Yes, N (\%) & No, N (\%) & Total, N (\% o.t.) & \\
\hline \multirow{9}{*}{$\begin{array}{l}\text { Application of EBVM } \\
\text { ignores clinical } \\
\text { experience }\end{array}$} & Strongly & $18(6.5)$ & $5(4.1)$ & $23(5.7)$ & \multirow{9}{*}{$\begin{array}{l}\chi^{2}=13.947 \\
\text { and } p<0.05\end{array}$} \\
\hline & Disagree & & & & \\
\hline & Disagree & $129(46.2)$ & $41(33.3)$ & $170(43.3)$ & \\
\hline & Middle & $96(34.4)$ & $46(37.4)$ & $142(35.3)$ & \\
\hline & Ground & & & & \\
\hline & Agree & $31(11.1)$ & $23(18.7)$ & $54(13.4)$ & \\
\hline & Strongly & $5(1.8)$ & $8(6.5)$ & $13(3.2)$ & \\
\hline & Agree & & & & \\
\hline & $\begin{array}{l}\text { Total } \quad(\% \\
\text { o.t. })\end{array}$ & $279(69.4)$ & $123(30.6)$ & $402(100.0)$ & \\
\hline \multirow[t]{6}{*}{ EBVM is impractical } & $\begin{array}{l}\text { Strongly } \\
\text { Disagree }\end{array}$ & $28(10.0)$ & $3(2.4)$ & $31(7.7)$ & \multirow[t]{6}{*}{$\begin{array}{l}\chi^{2}=37.886 \\
\text { and } p<0.05\end{array}$} \\
\hline & Disagree & $155(55.4)$ & $41(33.3)$ & $196(48.6)$ & \\
\hline & $\begin{array}{l}\text { Middle } \\
\text { Ground }\end{array}$ & 81 (28.9) & $56(45.5)$ & $137(34.0)$ & \\
\hline & Agree & $15(5.4)$ & $19(15.4)$ & $34(8.4)$ & \\
\hline & $\begin{array}{l}\text { Strongly } \\
\text { Agree }\end{array}$ & $1(0.4)$ & $4(3.3)$ & $5(1.2)$ & \\
\hline & $\begin{array}{ll}\text { Total } & (\% \\
\text { o.t. }) & \end{array}$ & $280(69.5)$ & $123(30.5)$ & $403(100.0)$ & \\
\hline \multirow{4}{*}{$\begin{array}{l}\text { Through EBVM my } \\
\text { clinical autonomy is } \\
\text { lost or reduced }\end{array}$} & $\begin{array}{l}\text { Strongly } \\
\text { Disagree }\end{array}$ & $47(16.9)$ & $11(9.2)$ & $58(14.6)$ & \multirow[t]{4}{*}{$\begin{array}{l}\chi^{2}=17.988, \\
\text { and } p<0.05\end{array}$} \\
\hline & Disagree & $150(54.0)$ & $48(40.0)$ & $198(49.7)$ & \\
\hline & Middle & $62(22.3)$ & $45(37.5)$ & $107(26.9)$ & \\
\hline & Ground & & & & \\
\hline
\end{tabular}




\begin{tabular}{|c|c|c|c|c|c|}
\hline \multirow[t]{2}{*}{ Variables } & & \multicolumn{3}{|c|}{ Do you practise EBVM? } & \multirow[t]{2}{*}{ P-value $\left(\chi^{2}\right)$} \\
\hline & & Yes, N (\%) & No, N (\%) & Total, N (\% o.t.) & \\
\hline & Agree & $15(5.4)$ & $13(10.8)$ & $28(7.0)$ & \\
\hline & Strongly & $4(1.4)$ & $3(2.5)$ & $7(1.8)$ & \\
\hline & Agree & & & & \\
\hline & $\begin{array}{l}\text { Total } \quad(\% \\
\text { o.t.) }\end{array}$ & $278(69.8)$ & $120(30.2)$ & $398(100.0)$ & \\
\hline
\end{tabular}

As outlined in Table 11, most survey participants agreed (56.2\%) or strongly agreed (12.7\%) that they are confident in evaluating scientific evidence. Those who practise EBVM, were more likely to agree than those who do not (Pearson Chi-Square statistic, $\chi^{2}=27.745$, and $p<0.05$ ). This finding suggests that the ability to evaluate scientific evidence is not considered to be a large barrier to practising EBVM by most respondents.

Overall 53.3\% of respondents stated to have received sufficient training to find evidence and solve clinical problems. Those who practise EBVM are more likely to have received sufficient training in finding evidence to solve clinical problems (Pearson Chi-Square statistic, $\chi^{2}=19.107$, and $p<0.05$ ).

One option to improve the adaptation of EBVM is to involve vet nurses in the training process more. Most respondents agreed $(38.3 \%)$ or strongly agreed $(15 \%)$ with the statement, with those practising EBVM being more in favour of a greater inclusion of vet nurses than those who do not. (Pearson Chi-Square statistic, $\chi^{2}$ $=14.863$, and $p<0.05)$.

Table 11: The ability to put EBVM into practice

\begin{tabular}{|c|c|c|c|c|c|}
\hline \multirow[t]{2}{*}{ Variables } & & \multicolumn{3}{|c|}{ Do you practise EBVM? } & \multirow[t]{2}{*}{ P-value $\left(\chi^{2}\right)$} \\
\hline & & Yes, N (\%) & No, N (\%) & Total, N (\% o.t.) & \\
\hline \multirow{9}{*}{$\begin{array}{l}\text { I am confident in } \\
\text { evaluating scientific } \\
\text { evidence to make } \\
\text { reliable clinical } \\
\text { decisions }\end{array}$} & Strongly & $1(0.4)$ & $5(4.1)$ & $6(1.5)$ & $\chi^{2}=27.745$, \\
\hline & Disagree & $22(7.9)$ & $17(13.8)$ & $39(9.7)$ & \\
\hline & Middle & 46 (16.5) & $34(27.6)$ & 80 (19.9) & \\
\hline & Ground & & & & \\
\hline & Agree & $164(58.8)$ & $62(50.4)$ & $226(56.2)$ & \\
\hline & Strongly & $46(16.5)$ & $5(4.1)$ & $51(12.7)$ & \\
\hline & Agree & & & & \\
\hline & Total & 279 (69.4) & $123(30.6)$ & $402(100.0)$ & \\
\hline & o.t.) & & & & \\
\hline \multirow{4}{*}{$\begin{array}{l}\text { I have received } \\
\text { sufficient training to } \\
\text { find evidence to } \\
\text { solve clinical } \\
\text { problems }\end{array}$} & Strongly & $7(25)$ & $8(66)$ & $15(38)$ & \multirow{4}{*}{$\begin{array}{l}\chi^{2}=19.107 \\
\text { and } p<0.05\end{array}$} \\
\hline & Disagree & & & & \\
\hline & Disagree & $37(13.3)$ & $27(22.1)$ & $64(16.0)$ & \\
\hline & Middle & $67(24.1)$ & $41(33.6)$ & $108(27.0)$ & \\
\hline
\end{tabular}




\begin{tabular}{|c|c|c|c|c|c|}
\hline \multirow[t]{2}{*}{ Variables } & & \multicolumn{3}{|c|}{ Do you practise EBVM? } & \multirow[t]{2}{*}{ P-value $\left(\chi^{2}\right)$} \\
\hline & & Yes, N (\%) & No, N (\%) & Total, N (\% o.t.) & \\
\hline & Agree & $133(47.8)$ & $39(32.0)$ & $172(43.0)$ & \\
\hline & $\begin{array}{l}\text { Strongly } \\
\text { Agree }\end{array}$ & $34(12.2)$ & $7(5.7)$ & $41(10.3)$ & \\
\hline & $\begin{array}{l}\text { Total } \quad(\% \\
\text { o.t. })\end{array}$ & $278(69.5)$ & $122(30.5)$ & $400(100.0)$ & \\
\hline \multirow{6}{*}{$\begin{array}{l}\text { Vet nurses/techs } \\
\text { should play a greater } \\
\text { role in undertaking } \\
\text { clinical research }\end{array}$} & $\begin{array}{l}\text { Strongly } \\
\text { Disagree }\end{array}$ & $4(1.4)$ & $5(4.2)$ & $9(2.3)$ & $\begin{array}{l}\chi^{2} \quad=14.863, \\
\text { and } p<0.05\end{array}$ \\
\hline & Disagree & $17(6.1)$ & $12(10.0)$ & $29(7.3)$ & \\
\hline & $\begin{array}{l}\text { Middle } \\
\text { Ground }\end{array}$ & 95 (33.9) & $54(45.0)$ & $149(37.3)$ & \\
\hline & Agree & $113(40.4)$ & $40(33.3)$ & $153(38.3)$ & \\
\hline & $\begin{array}{l}\text { Strongly } \\
\text { Agree }\end{array}$ & $51(18.2)$ & $9(7.5)$ & $60(15.0)$ & \\
\hline & $\begin{array}{l}\text { Total } \quad \text { (\% } \\
\text { o.t.) }\end{array}$ & $280(70.0)$ & $120(30.0)$ & $400(100.0)$ & \\
\hline
\end{tabular}




\section{Overcoming the barriers}

Respondents were asked to read each statement below (as listed in Table 12) and rank the following methods of increasing adoption of EBVM from best to worst (please answer even if you are currently not practising EBVM/are unsure). $1=$ most important/best and $5=$ least importance/worst. As shown in Table 5 , on average, "training opportunities" received the best score (2.60), followed by "journal clubs" (2.97), "discussion forums" (3.05), "paid time for research" (3.16) and "encouragement from my line manager/employer" (3.22).

Table 12: Methods of increasing the adoption of EBVM

\begin{tabular}{lll} 
Option & $\begin{array}{l}\text { Average score } \\
\text { (all respondents) }\end{array}$ & $\begin{array}{l}\text { Average score } \\
\text { (employees only) }\end{array}$ \\
\hline Training opportunities & 2.60 & 2.74 \\
Journal clubs & 2.97 & 3.02 \\
Discussion forums & 3.05 & 3.39 \\
Paid time for research (i.e. allocated time in my daily & & \\
work day) & 3.16 & 2.83 \\
Encouragement from my line manager/employer & 3.22 & 3.02 \\
\hline
\end{tabular}

On average, for all respondents ( $n=349)$, "training opportunities" received the best scores $(2.60)$ from survey participants, this was followed by "journal clubs" (2.97) and "discussion forums" (3.05). The two options to receive the lowest scores wore "paid time for research" (3.16) and "encouragement from my line manager/employer" (3.22). This ranking changed, when taking into account only the scores of employees ( $n=180)$, where training opportunities still received the best scores (2.74), but "paid time for research" now received the second highest scores (2.83). These findings suggest that opportunities need to be targeted depending on which group of veterinary professionals is being addressed.

Further to these findings, the distribution of responses shows that 'training opportunities' was mainly chosen in first, second or third place while "paid time for research" and "encouragement from my line manager/employer" was strongly favoured my some but also chosen as last option by other respondents (Figure 1). This finding highlights the importance of targeting the right opportunities to the right group of professionals. Future studies should further analyse the characteristics of those respondents, in order to effectively tailor programmes to increase EBVM to the right groups.

Figure 1: Distribution of responses to the question of methods to increase the adoption of EBVM

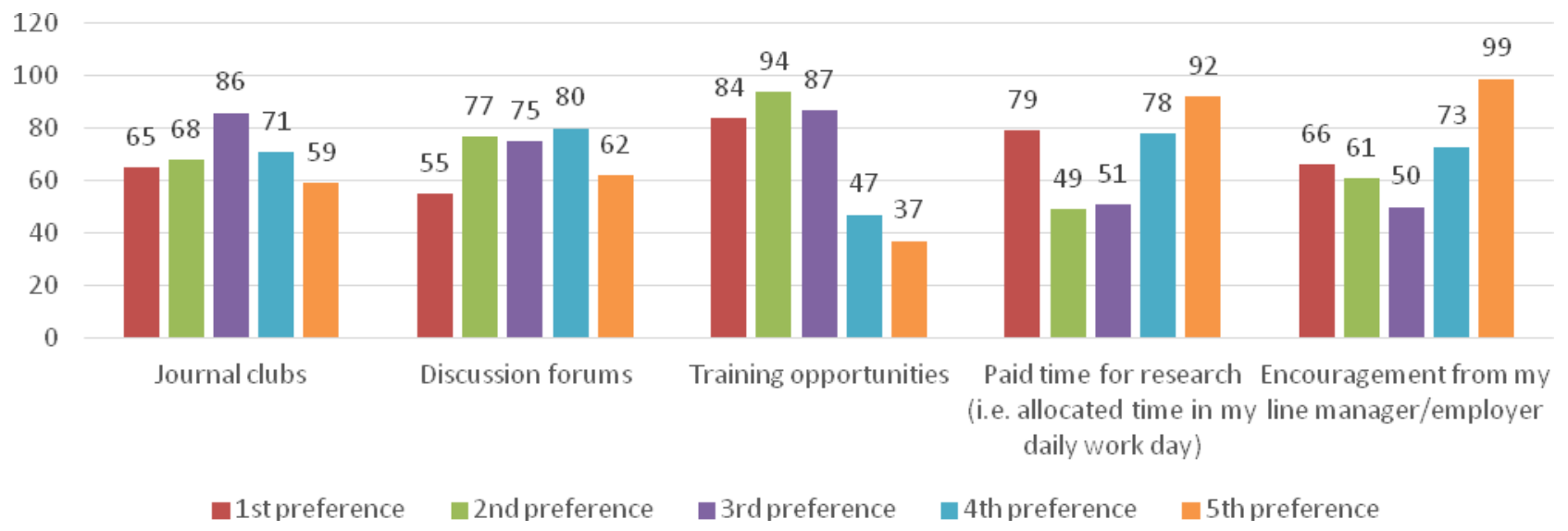


The survey responses of 407 veterinary professionals provided evidence on how EBVM is practised, how EBVM impacts client behaviour and employee engagement, what the barriers are to practising EBVM and how these could be overcome.

The Vet Futures initiative (http://www.vetfutures.org.uk/), a collaboration between the Royal College of Veterinary Surgeons and the British Veterinary Association, has yielded much contemporary knowledge about how further work needs to be carried out on the veterinary workforce and its leadership, communicating veterinary fees and value, focusing on reflective practice and supporting the Royal College of Veterinary Surgeons' Mind Matters Initiative (http://www.vetmindmatters.org/). This research has particularly important implications for the latter. VNFutures (2016) cites research from The Mind Matters Initiative that found increasing public expectations and professional isolation to be amongst some of the casual factors associated with stress in the veterinary and veterinary nursing professions. While our study does not reveal any indisputable relationships between EBVM and improved practice competitive advantage, creating savings for clients or reducing in-practice waste, we have been able to show that practicing EBVM does create a collegiate atmosphere amongst those who practice it and does provide clinicians with a feeling of confidence in their day-to-day activities. The veterinary professions are dedicated to improving the work environments of people in practice and the results of this research go some way into supporting their efforts.

This study provides clear evidence on what practising EBVM entails for veterinary professionals, with most respondents (62.0\%) having performed a literature search in order to influence clinical practice less than one month ago and spending 2-5 hours per month researching the literature. Most respondents (60.4\%) have access to online research platforms such as Pubmed and most veterinary professionals $(60.0 \%)$ state they practise veterinary medicine that is based on current research. There is an almost even split in participants who have and have not contributed to scientific research, however a clear majority of participants (80.2\%) have not contributed to scientific research in the last 12 months, which suggests the pool of the veterinary professionals surveyed does not only reflect the views of those in research and higher academic institutions. Interestingly most participants $(71.6 \%)$ do not attend journal clubs or discussion forums regularly, despite that being one of the top priorities when looking at ways to overcome the barriers to EBVM.

One of the key non-clinical benefits to come out of this study is the finding that practising EBVM has a very positive effect on employee engagement. Most survey participants agreed with the statement that EBVM makes them feel like they have provided the best medical care for their patient (88.4\%). Most respondents agree or strongly agree (80.2\%) with the statement: "I frequently share research and clinical experience with colleagues". The majority of respondents either agree or strongly agree (83.4\%) with the following statement: "EBVM gives me more confidence in clinical decision making". Those practising EBVM are more likely to find EBVM an inspiring and intellectual challenge, than those who do not. These findings suggest that EBVM could become an increasingly important topic when talking about attracting new employees and keeping these employees engaged.

Another important finding was that the majority of respondents stated that EBVM helps overcome the unknown (76.2\%), even out of those not actively practising EBVM, many agreed. Most respondents (63.6\%) believe that EBVM provides the best value to the customer and more than half (62.3\%) believe EBVM to be a method to build trust with clients. Respondents were somewhat more likely to agree than disagree with the following statement: "Clients are more invested in treatment choice through EBVM". The majority of respondents either agreed (50.1\%) or strongly agreed $(23.8 \%)$ with the following statement: "Clients appreciate when I put in extra work researching their specific case". For this question, no significant difference 
in associations was found between the two groups. Respondents are slightly more likely to think that clients appreciate an evidence-based approach, than not.

There is however no clear evidence that practising EBVM provides a competitive advantage over other practices, and there is no conclusive evidence that EBVM saves the client money, which is likely due to the fact that EBVM in itself does not always take into account treatment cost and sometimes favours further diagnostics and longer treatment options. The veterinary professionals surveyed did not provide conclusive evidence if clients are less likely to seek out a different practice if a vet practises EBVM. Interestingly most survey participants agreed or strongly agreed (76.4\%) with the statement: "Clients are unaware of EBVM". Those who do not practise EBVM are significantly more likely to strongly agree (48\%), than those who do practise EBVM (28\%). This provides an opportunity for further research, as the perspectives of the clients are key to verify this opinion held by veterinary professionals. The mixed responses on client engagement also provide an opportunity for greater education of clients on the practice of EBVM, and the clinical benefits it can yield.

The two most clearly identified barriers to practising veterinary medicine were time and free information. Most respondents (60.1\%) state that there is not enough time to practise EBVM and that information is not freely available (59.0\%). Overall $67.5 \%$ of survey participants agreed or strongly agreed that clinical practice is often based on anecdotal evidence. This suggests that there is scope to expand the practice of EBVM further.

On several other issues, further research is required to obtain conclusive evidence. For example, this study found no clear consensus on whether the evidence available is of low quality. No strong evidence was found that "Clients do not want lengthy, diagnosis laden treatment options". The survey delivered no clear finding on whether eminence based veterinary medicine is taught at vet schools or not.

A positive finding was, that some of the barriers the researchers expected, were not perceived as such, by a large portion of the veterinary professionals surveyed. Most respondents did not agree (48\%) with the following statement: "Application of EBVM ignores clinical experience." This suggests, that the perception of EBVM undermining a veterinarians' clinical experience is only perceived as a barrier by a minority of vets. Interestingly only $9.6 \%$ of respondents agreed or strongly agreed with the statement that EBVM is impractical. This suggests that impracticality is not perceived to be a barrier to practising EBVM by most survey respondents. Survey respondents largely disagreed (49.7\%) or strongly disagreed (14.6\%) with the statement that through EBVM their clinical autonomy is lost or reduced. Overall 53.3\% of respondents said they have received sufficient training to find evidence and solve clinical problems. Most responses agreed (56.2\%) or strongly agreed (12.7\%) that they are confident in evaluating scientific evidence.

One of the limitations of this study was the use of convenience sampling. Through the use of this sampling technique, the survey results do not accurately represent the industry. Due to the channels used to disseminate the survey, the study is likely to over-represent the small animal sector. The majority of survey participants were veterinarians, thus the results are unlikely to be representative of the views of vet nurses and technicians. While this paper establishes that a greater involvement of vet nurses is viewed favourably my many participants, further research on how to integrate vet nurses in the practice of EBVM, is needed.

Further, participation in the study was voluntary. It is also important to note that this study addresses EBVM as a concept and while it aims to provide evidence on what EBVM looks like in practice, it does not cover specific practices. Further analysis, including cost effectiveness analysis is needed to further detail the financial benefits of specific aspects of EBVM.

As the results of this study portray the opinions of veterinary professionals, further research is needed to obtain the perspective of clients, to test whether clients are aware of EBVM and how the practice of EBVM is viewed by clients. 
To conclude, the results of this study suggest that the practice of EBVM is a virtue for supporting current initiatives aimed at improving the work environment of the UK veterinary professions. There is no suggestion made herein that tangible, measurable business performance will be increased as a result of implementing EBVM. We do, however, recommend encouraging the practice of EBVM as it closely aligns with the values of so many initiatives being undertaken in the professions, such as Vet Futures, VN Futures and the Mind Matters Initiative.

\section{METHODS \& MATERIALS}

A PICO-based literature review was conducted by Hauser and Jackson (2016) to establish current knowledge about the non-clinical benefits of EBVM and yielded few answers to the research questions of this project. With the limited knowledge generated from this activity, an interview guide containing broad, open-ended questions was developed to explore three key themes that emerged from the sparse existing knowledge: the definition of EBVM, the benefits of EBVM, the barriers to the adoption of EBVM and ideas for exploring the broader adoption of EBVM. This interview guide, the information sheet about the project and the consent form to be signed by research participants was scrutinised and approved by the Royal Veterinary College's Clinical Research Ethical Review Board (Approval \#2015 1457).

The results of the interviews were used to create an online survey that empirically tested the tacit knowledge documented in Jackson and Hauser (2017). The survey, comprised of 23 questions, aimed through a range of questions to:

- Define EBVM and get an insight into EBVM looks like in practice

- Outline the non-clinical benefits of EBVM including: improving relationships with clients, achieving a sense of pride in one's work and employee engagement

- Outline the main barriers to wider implementation of EBVM: time and access

- Suggest ways of overcoming those barriers including more training opportunities and access to journal clubs.

The online survey was piloted on five UK vets and was not substantially altered beyond being released; the only major change that was strongly recommended by all pilot participants was that a definition of EBVM be included at the beginning of the survey.

The survey 'went live' via Survey Monkey on 5 September, 2016 and was closed on 10 October, 2016. The link to the survey was circulated on social media (Facebook and Twitter) by the RVC and RCVS Knowledge. RCVS Knowledge and the RCVS also published the link to the survey in their respective e-newsletters. The researchers' networks were also utilised and the link to the survey was circulated within Vets4Pets, Vets Now, Medi Vet, Goddard Veterinary Group and SPVS. We are grateful for the support of all of these organisations in helping to achieve a sample size of 407 usable responses. Survey participation was voluntary and the data was analysed anonymously. All statistical analyses were performed using the SPSS statistical package. Comparison between groups was performed using the Pearson Chi-square (c2) test. The significance level was set as $\alpha=$ 0.05 .

CONFLICT OF INTEREST

Acknowledgments: We would like to thank RCVS Knowledge for its generous support of this project, our Coinvestigator: Graham Milligan MRCVS and all the interview and survey participants. We are also sincerely 
grateful to everyone who completed the on-line survey and to the veterinary businesses which circulated the survey amongst their staff.

Funding: RCVS Knowledge grants.

Competing interests: There are no areas of conflicting interest associated with this work.

\section{REFERENCES}

1. Hauser, S. and Jackson, E.L. (2016) Non-Clinical Benefits of Evidence-Based Veterinary Medicine.Veterinary Evidence, 1 (3), http://dx.doi.org/10.18849/ve.v1i3.34

2. Jackson, E.L. and Hauser, S. (2017) An Exploratory Study Investigating the Non-Clinical Benefits of Evidence-Based Veterinary Medicine. Veterinary Evidence, 2 (2), http://dx.doi.org/10.18849/ve.v2i2.97

3. Sackett, L, David. et al. (1996) Evidence based medicine: what it is and what it isn't. BMJ, 312 (71), p. 71. http://dx.doi.org/10.1136/bmj.312.7023.71

4. VNFutures (2016). VNFutures - Taking charge of our future together. [Available at]: http://www.vetfutures.org.uk/resource/vn-futures-report-and-action-plan/ 


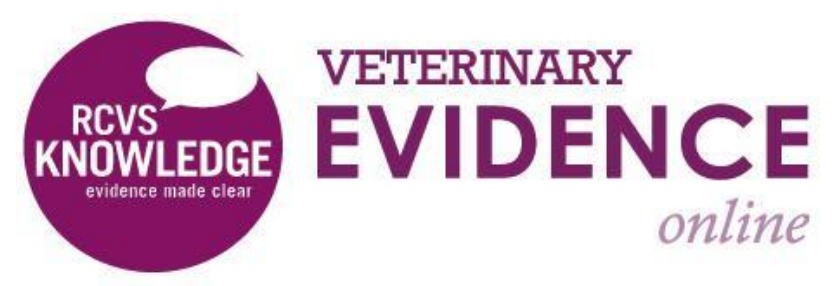

\begin{abstract}
Intellectual Property Rights
Authors of Articles submitted to RCVS Knowledge for publication will retain copyright in their work, but will be required to grant to RCVS Knowledge an exclusive license of the rights of copyright in the materials including but not limited to the right to publish, re-publish, transmit, sell, distribute and otherwise use the materials in all languages and all media throughout the world, and to license or permit others to do
\end{abstract} so.

Authors will be required to complete a license for publication form, and will in return retain certain rights as detailed on the form.

Veterinary Evidence and EBVM Network are RCVS Knowledge initiatives. For more information please contact us at editor@veterinaryevidence.org.

RCVS Knowledge is the independent charity associated with the Royal College of Veterinary Surgeons (RCVS). Our ambition is to become a global intermediary for evidence based veterinary knowledge by providing access to information that is of immediate value to practicing veterinary professionals and directly contributes to evidence based clinical decision-making.

www.veterinaryevidence.org

RCVS Knowledge is a registered Charity No. 230886. Registered as a Company limited by guarantee in England and Wales No. 598443.

Registered Office:

Belgravia House

62-64 Horseferry Road London SW1P 2AF

This work is licensed under a Creative Commons Attribution 4.0 International License. 